\title{
Is Green Growth Relevant for Poor Economies?
}

\author{
EDWARD B. BARBIER
}

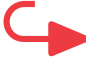

EdwARd B. BARbIER is the John S Bugas Professor of Economics, Department of Economics and Finance, University of Wyoming. His main expertise is natural resource and development economics as well as the interface between economics and ecology.

\section{Abstract}

To be relevant to developing countries, green growth must be reconciled with the two key structural features of natural resource use and poverty in these countries. First, primary products account for the majority of their export earnings, and they are unable to diversify from primary production. Second, many economies have a substantial share of their rural population located on less favored agricultural land and in remote areas, thus encouraging "geographic" poverty traps. If green growth is to be a catalyst for economy-wide transformation and poverty alleviation in developing countries, then it must be accompanied by policies aimed directly at overcoming these two structural features. Policies and reforms should foster forward and backward linkages of primary production, enhance its integration with the rest of the economy, and improve opportunities for innovation and knowledge spillovers. Rural poverty, especially the persistent concentration of the rural poor on less favored agricultural lands and in remote areas, needs to be addressed by additional targeted policies and investments, and where necessary, policies to promote rural-urban migration.

Keywords: green growth, structural change, rural poverty, less favored agricultural lands, remote areas, market access, primary products, resource dependency.

\section{JEL classification : Q15, 013, $0_{44}$}

\section{Acknowledgments :}

This paper is based on a keynote address to the 3rd International Conference: Environment and Natural Resources Management in Developing and Transition Economies, CERDI, Clermont University, ClermontFerrand, France, 8-10 October 2014. I am grateful for the Fondation pour les Études et Recherches sur le Développement International (Ferdi) for financial support. An earlier version of this paper was also presented as a Plenary Address at the Seminar on "Green Growth: Possible and Desirable?" at the World Bank, Washington, D.C. 13 May 2013. I am grateful to Pascale Combes Motel, Jaime De Melo and Michael Toman for comments and suggestions. 



\section{Introduction}

Much discussion is occurring in the international community about policy strategies for promoting a transition to a green economy, or "green growth" (OECD 2011; UNEP 2011; World Bank 2012). A typical definition is that "green growth means fostering economic growth and development while ensuring that natural assets continue to provide the resources and environmental services on which our well-being relies" (OECD 2011, p. 9). In short, "in a green economy, growth in income and employment should be driven by public and private investments that reduce carbon emissions and pollution, enhance energy and resource efficiency, and prevent the loss of biodiversity and ecosystem services." (UNEP 2011, p. 16).

The international policy fora discussing green growth have multiplied in recent years. The Green Growth Knowledge Platform is one such multi-lateral initiative, established by the Global Green Growth Institute, the Organization for Economic Co-operation and Development (OECD), the United Nations Environment Programme (UNEP) and the World Bank (see http://www.greengrowthknowledge.org/). The Group of 20 largest and richest economies pledged at its 2012 Mexico summit to promote "a focus on inclusive green growth as part of our G20 agenda", which continues to be a policy topic at subsequent summits. ${ }^{1}$ Greening the world economy was also a major theme of the June 2012 Rio+20 conference on environment and development (UNCSD 2012), which was attended by heads of state and finance ministers from most countries.

Recently, an important debate has emerged over whether the goal of green growth is relevant for low and middle-income countries, and if so, what additional policies may be needed to foster such a transition in developing countries (Barbier 2012a and 2012b; Dercon 2012; OECD 2013; Scott et al. 2013). This debate has raised concerns about the various challenges facing developing countries in implementing green growth, including a large informal economy, high levels of poverty and inequality, weak capacity and resources for innovation and investment, and inadequate governance and institutions. Given these challenges, "developing countries are understandably concerned that pursuing green growth could undermine their short-term economic growth and development" (OECD 2013, p. 8).

This paper argues that this concern is justified, unless green growth can be reconciled with the key structural features of natural resource use and poverty in most developing countries, which underlie two stylized facts. The first is that, for many low and middle-income economies, primary products account for the majority of their export earnings, and one or two primary commodities make up the bulk of exports. The result is that these economies remain highly dependent on the exploitation of land and natural resources and are unable to diversify from primary production. The

\footnotetext{
1 “G20 Leaders Declaration”, Las Cabos, Mexico, 18-19 June 2012.

http://www.g20.org/images/stories/docs/g20/conclu/G20 Leaders Declaration 2012.pdf. The members of the G20 include 19 countries (Argentina, Australia, Brazil, Canada, China, France, Germany, India, Indonesia, Italy, Japan, Mexico, Russia, Saudi Arabia, South Africa, South Korea, Turkey, the UK and the US) plus the European Union.
} 
second stylized fact is that many of these economies have a large share of their rural populations located on less favored (marginal) agricultural land and remote areas. The result may be the persistence of "geographic" poverty traps in these remote rural regions.

The implications of these stylized facts is that green growth can be relevant for developing economies only if it includes policies that are consistent with these economies' key structural features of natural resource use and poverty. To explain why, the paper first argues that, if green growth is to have relevance to developing countries, it must be compatible with the most important development goal, which is poverty alleviation. Here, the evidence is mixed. Not only does green growth involve key policy tradeoffs, but any shift from growth to green growth will have distributional implications, and it will be important to identify those policies that will favor or hurt the poor, even if their overall impact is to increase economic output or welfare. Next, the paper reviews the evidence on the two stylized facts of the spatial distribution of rural populations on less favored and remote agricultural land and of the resource dependency of many developing economies. These two structural features further compound the relevance of green growth to poverty alleviation, as policies - "green" or otherwise - that focus solely on promoting growth of industries and highly commercialized agricultural and service activities in developing are unlikely to benefit the rural poor on less favored and remote agricultural lands or end the current "enclavism" predominating in primary production and resource-based activities of developing countries. Thus, additional policies are required to address the two stylized facts of rural poverty and resource dependency: targeted policies for the rural poor on less favored and remote agricultural lands, and policies to improve the efficiency and sustainability of primary production for more economy-wide gains.

The outline of the paper is as follows. The next section discusses the policy tradeoffs implied by green growth, and especially their relevance to poverty alleviation in developing countries. This is followed by a review of the evidence of the two key structural features of natural resource use and poverty in developing countries. The implications of these stylized facts for green growth are explained, especially the need for additional policies that tackle these structural features more directly. The paper concludes with some final remarks on green growth and developing countries.

\section{Green growth, policy tradeoffs and poverty alleviation}

According to the OECD (2013), emerging evidence suggests that green growth in developing countries can lead to poverty reduction, economic growth, reduced vulnerability to climate change and natural disasters, greater energy security, and more secure livelihoods for those directly dependent on the use of natural resources. The fact that proponents of green growth believe that it has the potential to deliver "win-win" outcomes that can achieve simultaneously several desired policy outcomes in developing countries is one of its most attractive features. In some ways, this viewpoint is supported by the conceptual framework underlying green growth, which tries to draw on several economic policy perspectives. 
For example, Bowen and Frankhauser (2012) suggest that policies advocated to achieve green growth usually draw on four different policy perspectives in economics :

- Keynesian perspective - mitigate short-term macroeconomic fluctuations, unemployment, fiscal sustainability and global imbalances.

- Pigouvian perspective - implement market-based instruments, regulations, subsidy removal, etc. to "internalize" environmental externalities.

- Schumpterian perspective - innovation and research and development (R\&D) to foster new "green" industries, technological change and development.

- Georgian perspective - mitigate resource scarcity, through substituting away from scarce resources such as fossil fuels and thus removing a constraint to long-term growth.

Pursuing simultaneously these different policy approaches must inevitably involve tradeoffs. For example, Strand and Toman (2010) point out potential tradeoffs between short-term macroeconomic goals, such as economic stimulus and job creation, and long-term environmental goals, such as mitigating resource scarcity, greenhouse gas reductions and environmental improvement. Barbier (2012b) further emphasizes the tradeoffs between local and immediate versus more global and long-term benefits inherent in key green growth policies. For example, the implementation of regulations on energy conservation is likely to be easier and imply fewer tradeoffs than the introduction of pricing policies on natural resources or the introduction of a global carbon tax.

Growth in conventionally measured output or gross domestic product (GDP) may not necessarily increase as a result of "green" policies (Hallegatte et al. 2011; Schmalensee 2012). Environmental regulation could reduce conventionally measured output growth, if other growth-benefiting efficiency gains or technology changes are discouraged or not possible. In addition, any shift from growth to green growth will have distributional implications on wealth and income.

These implications of the shift from growth to green growth are especially relevant to developing countries. As pointed out by Dercon (2012), if green growth is to have relevance for low and middle income economies, it must also be compatible with the most important development objective for these countries, which is poverty alleviation. Thus, even if the adoption of green growth policies increase overall economic output or welfare, it is still important to identify those policies that will favor or hurt the poor, to ensure that the shift from growth to green growth leads to poverty alleviation. Here, the evidence in developing countries is somewhat mixed.

For example, Dercon (2012) argues that environmental pricing and regulation may negatively impact the poor as consumers, and would require countervailing, specific social protection measures to compensate for price rises. The poor as producers may also be affected negatively, as they may not have sufficient access to the wealth nor the human capital required to substitute for more expensive energy or other natural resources. As the latter become more valuable, it may promote rent capture by the rich. Low-carbon and other environmental investments may require more technology and capital-intensive growth, which is unlikely to favor the poor. Finally, public 
"green" subsidies and investment may crowd out pro-poor programs, such as health care, education and agricultural R\&D.

Examples of some of these tradeoffs can be found in southern Africa, where the implementation of green growth policies appears to follow the similar pattern of most policy reforms that advocated the acceptance of short-term adjustment costs, especially among the poor, in the expectations of long-term gains (Resnick et al. 2012). These include reforms such as shifting away from environmentally harmful fertilizer subsidies in Malawi, reducing promotion of biofuels in Mozambique, such as sugar and jatropha, that encourage deforestation, and curtaining electricity generated from coal in South Africa. These reforms might be more environmentally friendly, but they may also disproportionately affect the incomes, livelihoods and employment of the poor.

Barbier (2014) has reviewed how various climate mitigation policies, which aim to reduce the greenhouse gas emissions, may impact poverty in developing countries. Policies, such as payments for avoided deforestation, changes in air quality and any resulting health effects, and energy, agricultural and transport innovations, have the potential for direct and positive impacts on alleviating poverty in developing countries. However, other mitigation polices may have more aggregate impacts on the trade and economic growth, which in turn can impact indirectly the poor via output markets (e.g. agricultural commodities, imported goods or consumption) or factor earnings (wages or land rent). These effects can be both positive and negative.

Even policies with potentially direct benefits for the poor may have some negative side effects. A study of the health implications of mitigation policies in four sectors - household energy, transport, food and agriculture, and electricity generation - indicates that, although the potential benefits are substantial, there are some possible negative impacts for poor households as well (Haines et al. 2009). For example, an improved cook stove program in India would require an upfront purchase of $\$ 50$ per household yet would reduce weekly fuel costs and save time. For poor households in India and China there would also be a trade-off between the health benefits from the reduced air pollution associated with low-carbon electricity generation and the higher energy costs and possible implications for fuel poverty. The study in São Paolo, Brazil on lowering consumption of animal products suggests the poor households are especially vulnerable to the possible negative nutritional consequences on childhood growth and development.

However, perhaps one of the most limiting features of green growth policies is that they presume a degree of structural transformation and industrial development that is more suited to high-income rather than developing economies. For example, Fankhauser et al. (2013, p. 903) "interpret green growth as an economy-wide transformation, rather than the expansion of the environmental goods and services sectors." The authors argue that there are several strategic sectors whose transformation is central to the creation of a green economy. These areas include industrial processes, which need to become cleaner and more resource efficient (e.g. iron and steel); sectors that are important for energy efficiency on the supply side (electricity distribution systems) and the demand side (domestic appliances); the energy supply chain for electricity generation and other 
industrial processes (steam generators; engines and turbines; electric motors and transformers); and car manufacturing (low-emission and electric vehicles) and key components (accumulators, primary cells and batteries). Not surprisingly, Fankhauser et al. (2013) find that the "green race" to become global competitive leaders in these industries is between eight high-income or large emerging market economies - China, France, Germany, Italy, Japan, South Korea, the United Kingdom and the United States."

Similarly, the Asian Development Bank (ADB and ADBI 2013, p. 18) identifies "low-carbon green growth" in Asia as "a process of structural change", which envision patterns of industrial development, patterns of specialization and innovation, "thereby defining low-carbon development as the capacity of an economy to generate new dynamic activities". Thus, a major component of this strategy is to ensure the dissemination from richer to poorer Asian countries of low-carbon and energy-saving technologies, the adaption and dissemination of these technologies throughout the economy, support for infant green firms, government procurement policies to achieve mainstream emission reduction targets, and public sector investments to support these industrial developments. In other words, the approach advocated is to enhance economy-wide "green" structural transformation through a combination of "public investment and industrial as well as trade policies, aiming at encouraging in both cases a strong private sector response" (ADB and ADBI 2013, p. 19).

\section{The structural features of the rural economy of developing countries}

In effect, the view of green growth as a process of structural transformation through industrial development and innovation is part of the renewed interest in how the structure of an economy influences its development. According to this perspective, "high-growth countries are those that are able to undertake rapid structural transformation from low-productivity ('traditional') to highproductivity ('modern') activities" (Rodrik 2010, p. 90). As these leading production activities have the inherent capacity to innovate with labor-augmenting technology through learning-by-doing, they create sector-wide knowledge spillovers that sustain growth (Lin 2011; McMillan and Rodrik 2011; Ocampo et al. 2009). The conclusion is that in developing economies "productivity growth is closely associated to dynamic structural change toward industry and modern services" (Ocampo et al. 2009, p. 122).

In contrast, the traditional and predominantly rural sector of developing economies is viewed as being relatively unproductive and incapable of dynamic structural change through learning-bydoing and knowledge spillovers. As a result, "when labor and other resources move from less productive to more productive activities, the economy grows even if there is not productivity growth within sectors" (McMillan and Rodrik 2011, p. 1). Such an emphasis on modern sector expansion as the engine of dynamic structural change and growth suggests that the structure of 
production within the rural economy, and especially natural resource and land use, has little significance to the overall development process. $^{2}$

However, as Kreuger (2011, p. 223) has pointed out, "ignoring the importance of increased productivity of the large fraction of the labor force (and of land) in rural areas" is a flawed approach to economic development. According to this view, structural change in developing countries requires policies and investments aimed specifically at improving the productivity and livelihoods of rural areas. Empirical evidence on the intractability of rural poverty in developing regions is often cited in support of this perspective. Rural poverty rates in developing economies have declined over the past decade but remain high in South Asia (40\%) and Sub-Saharan Africa (51\%), and where reductions in rural poverty have occurred, they are largely due to rural development and not rural-urban migration (World Bank 2008).

In sum, structural transformation - green or otherwise - will not be successful in shifting a developing economy to a more productive, innovative and sustainable growth path unless it can be reconciled with the key structural features of natural resource use and poverty in most developing countries. Although the modern sector may be the source of dynamic growth through learning-by-doing and knowledge spillovers, patterns of labor, land and other natural resource use in the rural economy matter in the overall dynamics of structural change. In most developing countries, the two most persistent structural features underlying these patterns are two stylized facts of natural resource use and poverty: many economies are resource-dependent and thus highly reliant on a commercial primary products sector, and they also have a "residual" pool of rural poor located on abundant but less favored (marginal) agricultural land and in remote areas.

\section{Resource dependency and economic development}

Increasingly, it is commercially oriented economic activities that are responsible for much of the resource exploitation and expansion of the agricultural land base through the conversion of forests, wetlands and other natural habitat that is occurring in developing economies (Boucher et al. 2011; Chomitz et al 2007; Deininger et al. 2011; DeFries et al. 2010; FAO 2006; Lambin and Meyfroidt 2011; Rudel 2007). The primary product activities responsible for extensive land conversion include plantation agriculture, ranching, forestry and mining activities, and often result in export-oriented extractive enclaves with little or no forward and backward linkages to the rest of the economy (Barbier 2005 and 2011; Bridge 2008; van der Ploeg 2011). In addition, developing countries have been actively promoting these commercial activities as a means to expanding the primary products sector, especially in the land and resource abundant regions of Latin America and Africa (Deininger and Bayerlee 2012; Rudel 2007). Developing countries will also require new land

\footnotetext{
${ }^{2}$ For example, Lin (2011, p. 200) argues: "Following the tradition of classical economics, economists tend to think of a given country's endowments as consisting only of its land (or natural resources), labor, and capital (both physical and human). These are in fact factor endowments, which firms in an economy can use in production. It should be noted that the analysis of new structural economics focuses on the dynamics of the capital/labor ratio. This is because land is exogenously given in any realistic discussion of a country's development and natural resources, such as mining resources, exist underground in fixed quantity and their discovery is often random."
} 
for biofuel crops, grazing pasture and industrial forestry, and also to replace land lost to degradation (Lambin and Meyfroidt 2011).

The result is that many developing economies remain highly dependent on the exploitation of natural resources and are unable to diversify from primary production as the dominant economic sector. Thus, their development remains largely resource dependent - as measured by the ratio of primary products to total merchandise exports (see Figure 1). However, among developing economies there are important regional differences. Since 1960, Asian countries have had the sharpest decline in resource dependency, as these economies have generally become more successful in diversifying their economies and developing labor-intensive manufacturing for exports. Latin America has also seen a decline in the ratio of primary products to total exports, especially in recent decades, but still around $50 \%$ of the exports from this region are resource commodities. But in Africa and the Middle East, resource dependency remains relatively high, around $80 \%$ for Middle East and North Africa and over 70\% for Sub-Saharan Africa.

Figure1. Resource dependency in exports by developing country region, 1960-2012

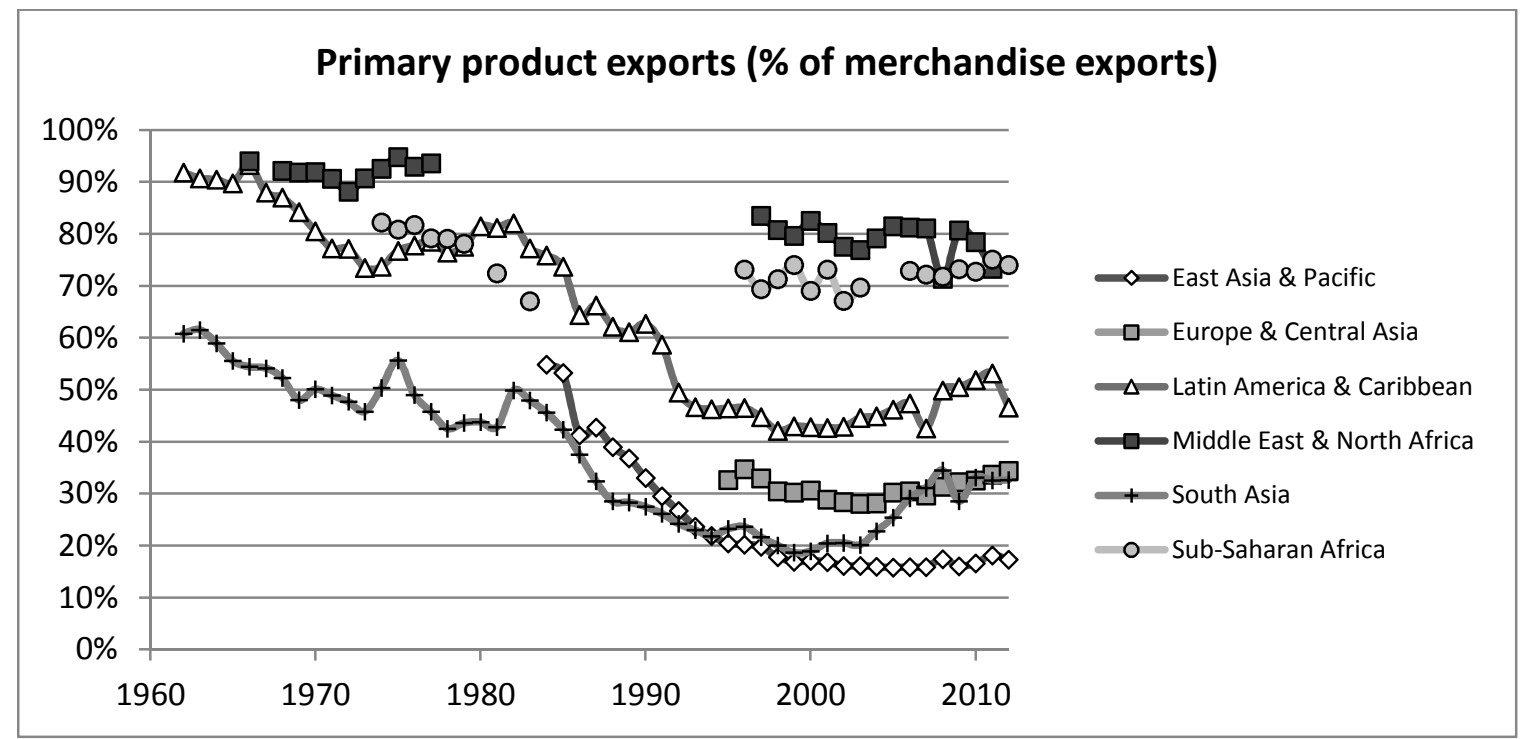

Primary product export share is the percentage of agricultural raw material, food, fuel, ore and metal commodities to total merchandise exports. Low and middle-income (or developing) countries are economies with 2013 per capita income of $\$ 12,745$ or less. High-income OECD countries are members of the Organization for Economic Cooperation and Development (OECD) in which 2013 GNI per capita was $\$ 12,746$ or more.

Source: World Bank, World Development Indicators, available from http://databank.worldbank.org/data

Resource dependency may be linked to other structural economic features of developing countries and regions. Table 1 shows how different developing country regions have varied over 2000 to 2012 not only in terms of resource dependency but also gross domestic product (GDP) per capita, adjusted net national income and savings, and poverty rates. For example, the East Asia and Pacific region of developing countries has the lowest share of primary products in total exports - lower than that of high-income economies - and a very high rate of adjusted net savings, but it also has relatively low income per capita and high poverty compared to other regions. At the other extreme, over $70 \%$ of the exports from Sub-Saharan Africa came from resource commodities and also has the lowest level of adjusted net national income per capita of any region. In addition, Sub- 
Saharan Africa had on average a slightly negative adjusted net savings rate over 2000 to 2012, and the highest poverty rate (73\%) of any developing region.

Table 1. Key development indicators by region, 2000-2012

\begin{tabular}{lccccc}
\hline Region & $\begin{array}{c}\text { Primary product } \\
\text { exports (\% of } \\
\text { merchandise }\end{array}$ & $\begin{array}{c}\text { GDP per capita } \\
\text { (2005 US\$) } \\
\text { exports) }\end{array}$ & $\begin{array}{c}\text { Adjusted net } \\
\text { national income } \\
\text { per capita } \\
\text { (2005 US\$) }\end{array}$ & $\begin{array}{c}\text { Adjusted net } \\
\text { savings } \\
\text { (\% of GNI) }\end{array}$ & $\begin{array}{c}\text { Poverty } \\
\text { headcount ratio } \\
\text { at \$2 a day (\% of } \\
\text { population) }\end{array}$ \\
East Asia \& Pacific & $16.5 \%$ & 1,871 & 1,554 & $28.6 \%$ & $38.5 \%$ \\
Europe \& Central Asia & $30.7 \%$ & 3,933 & 3,303 & $5.0 \%$ & $4.3 \%$ \\
Latin America \& Caribbean & $46.6 \%$ & 5,037 & 4,081 & $6.1 \%$ & $15.4 \%$ \\
Middle East \& North Africa & $78.7 \%$ & 2,237 & 1,391 & $5.7 \%$ & $15.8 \%$ \\
South Asia & $26.9 \%$ & 759 & 663 & $17.9 \%$ & $72.1 \%$ \\
Sub-Saharan Africa & $71.9 \%$ & 878 & 627 & $-0.1 \%$ & $72.7 \%$ \\
All low \& middle income & $32.6 \%$ & 1,849 & 1,502 & $15.5 \%$ & $46.1 \%$ \\
High income: OECD & $19.5 \%$ & 34,453 & 29,376 & $9.4 \%$ & -- \\
World & $25.6 \%$ & 7,212 & 6,041 & $11.0 \%$ & -- \\
\hline
\end{tabular}

The reported figures are the averages over 2000-2012 per region.

Primary product export share is the percentage of agricultural raw material, food, fuel, ore and metal commodities to total merchandise exports.

GDP per capita is gross domestic product divided by midyear population. GDP is the sum of gross value added by all resident producers in the economy plus any product taxes and minus any subsidies not included in the value of the products. It is calculated without making deductions for depreciation of fabricated assets or for depletion and degradation of natural resources. Data are in constant 2005 U.S. dollars.

Adjusted net national income per capita is gross national income (GNI) minus consumption of fixed capital and natural resources depletion, divided by midyear population.

Gross national income (GNI) is the sum of value added by all resident producers plus any product taxes (less subsidies) not included in the valuation of output plus net receipts of primary income (compensation of employees and property income) from abroad. Data are in constant 2005 U.S. dollars.

Adjusted net savings are equal to net national savings plus education expenditure and minus energy depletion, mineral depletion and net forest depletion. This series excludes particulate emissions and carbon dioxide damage.

Population below $\$ 2$ a day is the percentage of the population living on less than $\$ 2.00$ a day at 2005 international prices, using purchase power parity (PPP).

Low and middle-income (or developing) countries are economies with 2013 per capita income of $\$ 12,745$ or less. Highincome OECD countries are members of the Organization for Economic Cooperation and Development (OECD) in which 2013 GNI per capita was $\$ 12,746$ or more.

Source: World Bank, World Development Indicators, available from http://databank.worldbank.org/data

Figure 2 indicates how GDP per capita varies with resource dependency across low and middleincome countries. Developing countries that are extremely resource dependent, i.e. with a large share of primary products in total merchandise exports, have much lower GDP per capita than countries that export relatively less resource commodities. In particular, those economies that have a primary product export share of less than 30\% have 1.7-1.8 times more GDP per capita than countries with an export share of $70 \%$ or more. 
Figure 2. Resource dependency and GDP per capita in developing countries, 2000-2012

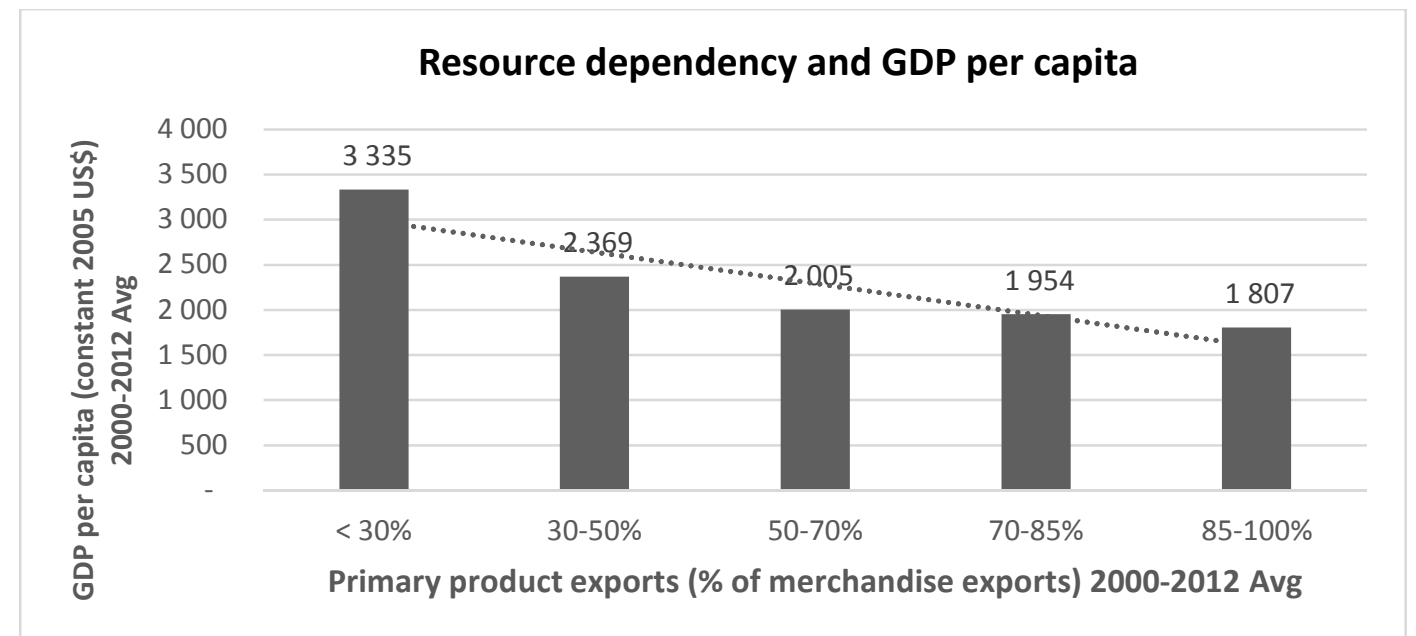

118 countries, of which 27 (primary product export share < 30\%), $20(30-50 \%), 20(50-70 \%), 26(70-85 \%)$ and 25 (85-100\%).

Primary product export share is the percentage of agricultural raw material, food, fuel, ore and metal commodities to total merchandise exports (average 58.8\%, median 64.0\%). GDP per capita is gross domestic product divided by midyear population (average $\$ 2,323$, median $\$ 1,557$ ).

Low and middle-income (or developing) countries are economies with 2013 per capita income of $\$ 12,745$ or less.

Source: World Bank, World Development Indicators, available from http://databank.worldbank.org/data

Finally, as noted previously, an important economic development objective is the alleviation of poverty, which is prevalent in all low and middle-income countries. However, as Figure 3 indicates, the poverty rate among developing countries varies considerably with resource dependency. For example, the percentage of the population that is poor is much higher for those countries that export at least $50 \%$ of their exports as primary products than for economies that have a lower export share. And, for those 21 economies that have a primary product export share of $85 \%$ or more, greater than have their populations are living in poverty.

To summarize, resource dependency is a key structural feature of many developing economies. For example, primary products account for at least half of all merchandise exports, for 71 out of the 118 developing countries for which there are export data (see Figure 2). In addition, resource dependency appears to be related to other important structural features of "underdevelopment" in these economies. As we have seen, more resource-dependent economies tend to have lower levels of GDP and adjusted net national income per capita, accumulate less savings after adjusting for capital and natural resource depreciation, and higher poverty rates. 
Figure 3. Resource dependency and poverty in developing countries, 2000-2012

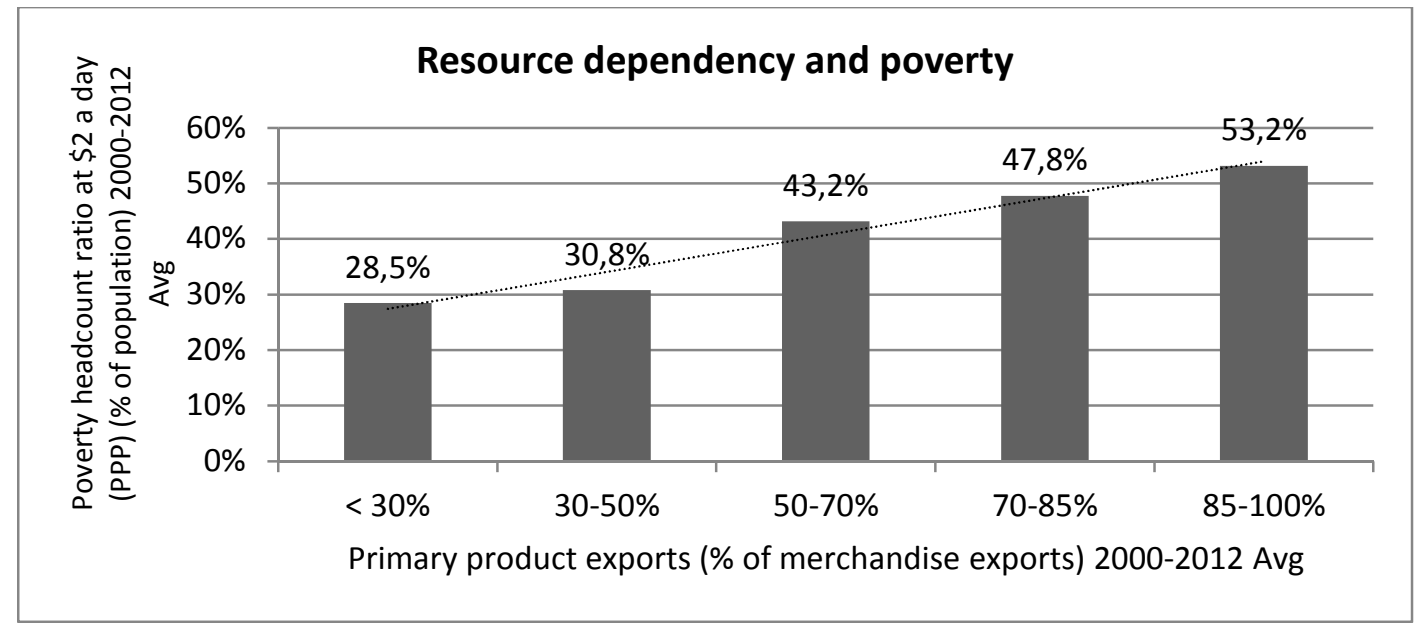

101 countries, of which 24 (primary product export share <30\%), $18(30-50 \%), 18(50-70 \%), 20(70-85 \%)$ and 21 (85-100\%).

Primary product export share is the percentage of agricultural raw material, food, fuel, ore and metal commodities to total merchandise exports (average $57.7 \%$, median $58.6 \%$ ). Population below $\$ 2$ a day is the percentage of the population living on less than $\$ 2.00$ a day at 2005 international purchase power parity (PPP) prices. For eight countries, the poverty headcount ratio is at national poverty line (\% of population). Across all countries, the average poverty rate was $40.5 \%$, and the median $35.5 \%$.

Low and middle-income (or developing) countries are economies with 2013 per capita income of $\$ 12,745$ or less.

Source: World Bank, World Development Indicators, available from http://databank.worldbank.org/data

\section{The spatial distribution of rural population, poverty and economic development}

In their review of the empirical evidence on poverty traps in developing countries, Kraay and McKenzie (2014, p. 143) state: "The evidence most consistent with poverty traps comes from poor households in remote rural regions". Certainly, recent studies of the spatial distribution of rural population on less favored agricultural lands and in remote areas of developing countries seem to support this claim.

One of the first studies to determine the distribution of the rural poor on less favored lands globally was CGIAR (1999), which concluded that nearly two-thirds of the rural population of developing countries -almost 1.8 billion people- live on less-favored lands, including marginal agricultural lands, forest and woodland areas, and arid zones. By applying national rural poverty percentages, CGIAR (1999) determined that 633 million poor people lived on less favored lands in developing countries, or around two-thirds of the total rural poor (see also CAWMA 2008).

A subsequent analysis by the World Bank (2003) sought to identify the percentage of total population in a selection of low and middle-income economies located on "fragile lands" in 2000. This classification comprised four categories of land: terrain greater than $8 \%$ median slope, soil unsuitable for rainfed agriculture, arid and dry semi-arid land without access to irrigation, and forests (deciduous, evergreen and mixed). The study estimated that nearly 1.3 billion people in 2000 - almost a fifth of the world's population - lived in such areas in developing regions, and concluded that since 1950, the estimated population in developing economies on "fragile lands" may have doubled (World Bank 2003). 
The World Bank (2008) employed the definition proposed by Pender and Hazell (2000) for less favored areas to determine the spatial distribution of rural populations in 2000. However, the analysis was able to determine only the distribution of rural population on lands limited by rainfall (arid and semi-arid lands) and in remote areas. The latter are defined as locations with poor market access, requiring five or more hours to reach a market town of 5,000 or more. Around 430 million people in developing countries in 2000 lived in such distant rural areas, and nearly half $(49 \%)$ of these populations were located in semi and semi-arid regions characterized by frequent moisture stress that limits agricultural production (World Bank 2008).

Using a variety of global spatially referenced data sets, Barbier and Hochard (2014a) analyze the spatial distribution of rural population across developing countries in 2000 on less favored agricultural lands and areas (see Table 2). Less favored agricultural land (LFAL) consists of irrigated land on terrain greater than $8 \%$ median slope; rainfed land with a length of growing period (LGP) of more than 120 days but either on terrain greater than $8 \%$ median slope or with poor soil quality; semi-arid land (land with LGP 60-119 days); and arid land (land with LGP < 60-119 days). Less favored agricultural areas (LFAA) include less favored agricultural lands plus favorable agricultural land that is remote; i.e., land in rural areas with high agricultural potential but with limited access to markets. Following Nelson (2008), market access is defined as less than five hours of travel to a market city with a population of 50,000 or more.

In 2000, most of the world's rural population on LFAL and LFAA were located in developing countries, over 1.3 billion and nearly 1.4 billion respectively (see Table 2). This amounts to over one third of the rural population in these countries. Almost $36 \%$ of the 2000 rural population in developing countries was located on such marginal agricultural land, although this share ranged from 23\% in Middle East \& North Africa to 56\% in Europe \& Central Asia. In 2000, around 1.6 billion people worldwide lived in less favored agricultural areas, with nearly 1.4 billion in low and middleincome economies. Over $37 \%$ of the rural population in developing countries was in less favored agricultural areas, with the share again varying from $23 \%$ in Middle East \& North Africa to nearly $56 \%$ in Europe \& Central Asia. Given the similarity in population distributions in Table 1, it is clear that nearly all the rural populations in less favored agricultural areas comprise people living on marginal agricultural land. Finally, Barbier and Hochard (2014a) also find that, of the 1.3 billion people in developing countries living on LFAL, over 288 million were located in remote areas with poor market access. This latter group is likely to be the most disadvantaged rural poor in developing countries. 


\begin{tabular}{|c|c|c|c|c|c|}
\hline \multicolumn{6}{|c|}{ Population in 2000 (millions) } \\
\hline & $\begin{array}{c}\text { Rural } \\
\text { population }\end{array}$ & $\begin{array}{l}\text { Rural population on } \\
\text { less favored } \\
\text { agricultural land } \\
\text { (LFAL) }\end{array}$ & $\%$ share & $\begin{array}{l}\text { Rural population in } \\
\text { less favored } \\
\text { agricultural areas } \\
\text { (LFAA) }\end{array}$ & $\%$ share \\
\hline & (1) & (2) & $(2) /(1)$ & (3) & $(3) /(1)$ \\
\hline \multirow{7}{*}{$\begin{array}{l}\text { Developing country } \\
\text { East Asia \& Pacific } \\
\text { Europe \& C. Asia } \\
\text { Latin America \& Caribbean } \\
\text { Middle East \& N. Africa } \\
\text { South Asia } \\
\text { Sub-Saharan Africa }\end{array}$} & $3,706.8$ & $1,314.5$ & $35.5 \%$ & $1,382.7$ & $37.3 \%$ \\
\hline & $1,398.4$ & 645.0 & $46.1 \%$ & 672.9 & $48.1 \%$ \\
\hline & 173.8 & 96.4 & $55.5 \%$ & 97.1 & $55.9 \%$ \\
\hline & 294.1 & 94.9 & $32.3 \%$ & 97.0 & $33.0 \%$ \\
\hline & 195.6 & 44.9 & $23.0 \%$ & 45.2 & $23.1 \%$ \\
\hline & $1,090.4$ & 269.0 & $24.7 \%$ & 291.0 & $26.7 \%$ \\
\hline & 554.6 & 164.3 & $29.6 \%$ & 179.5 & $32.4 \%$ \\
\hline Developed country & 404.7 & 171.8 & $42.4 \%$ & 173.8 & $42.9 \%$ \\
\hline World & $4,111.5$ & $1,486.3$ & $36.1 \%$ & $1,556.4$ & $37.9 \%$ \\
\hline
\end{tabular}

Less favored agricultural land (LFAL) consists of irrigated land on terrain greater than $8 \%$ median slope; rainfed land with a length of growing period (LGP) of more than 120 days but either on terrain greater than $8 \%$ median slope or with poor soil quality; semi-arid land (land with LGP 60-119 days); and arid land (land with LGP < 60 days). Less favored agricultural areas (LFAA) include less favored agricultural land as well as favored agricultural land with limited market access (i.e. located in remote areas). Market access is identified as less than five hours of travel to a market city with a population of 50,000 or more, as defined by Nelson (2008).

Developing countries are all low and middle-income economies with 2012 per capita income of $\$ 12,615$ or less, as defined by the World Development Indicators, available from http://databank.worldbank.org/data (World Bank 2014).

Column (1) is estimated for 205 countries. Columns (2) and (3) are estimated for 184 countries; one country was indeterminate due to changing political boundaries, and 20 countries had missing data or insufficient spatial resolution denoting agricultural land.

Source : Barbier and Hochard (2014a).

Moreover, the spatial distribution of rural population on LFAL and LFAA in developing countries appears to be increasing, not lessening. Whereas in developed countries the rural population on LFAL, LFAA and remote LFAL has declined over 2000-2010, it has risen substantially in developing countries, over $1 \%$ annually (see Table 3). In Sub-Saharan Africa, the annual growth exceeds $3 \%$. By 2010, the number of people worldwide on remote less favored agricultural land had increased to over 330 million, of which at least 320 million were in developing countries.

As indicated in Figure 4, the average poverty rate is higher in developing countries with greater shares of their rural population on remote less favored agricultural land. For example, the average 2000-2012 poverty rate is over $45 \%$ in countries with more than $10 \%$ of their rural population on remote LFAL in 2010, whereas it is just under 35\% than in countries with a $3 \%$ share or less. For countries with $5-10 \%$ of their rural population located in remote LFAL, the poverty rate is over $40 \%$. 
Table 3. Rural population on less favored agricultural lands and areas, 2000-2010 changes

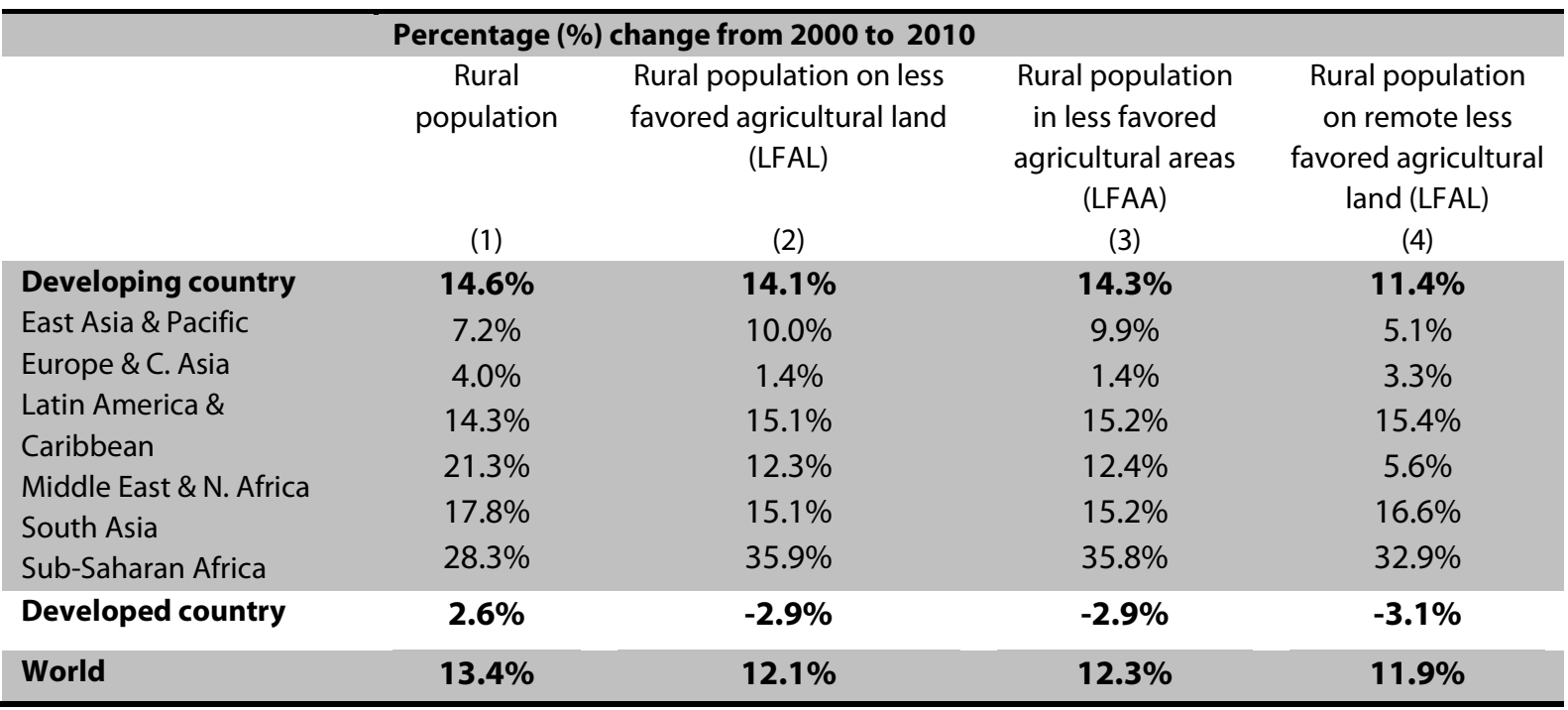

Less favored agricultural land (LFAL) consists of irrigated land on terrain greater than $8 \%$ median slope; rainfed land with a length of growing period (LGP) of more than 120 days but either on terrain greater than $8 \%$ median slope or with poor soil quality; semi-arid land (land with LGP 60-119 days); and arid land (land with LGP < 60 days). Less favored agricultural areas (LFAA) include less favored agricultural land as well as favored agricultural land with limited market access (i.e. located in remote areas). Market access is identified as less than five hours of travel to a market city with a population of 50,000 or more, as defined by Nelson (2008).

In 2010 , in developing countries, the rural population on LFAL was estimated to be 1.67 billion, on LFAA 1.75 billion, and on remote LFAL 332 million.

Developing countries are all low and middle-income economies with 2012 per capita income of $\$ 12,615$ or less, as defined by the World Development Indicators, available from http://databank.worldbank.org/data (World Bank 2014).

Column (1) is estimated for 205 countries. Columns (2) and (3) are estimated for 184 countries; one country was indeterminate due to changing political boundaries, and 20 countries had missing data or insufficient spatial resolution denoting agricultural land.

Source: Barbier and Hochard (2014a).

\section{Figure 4. Rural population on remote less favored agricultural land and poverty}

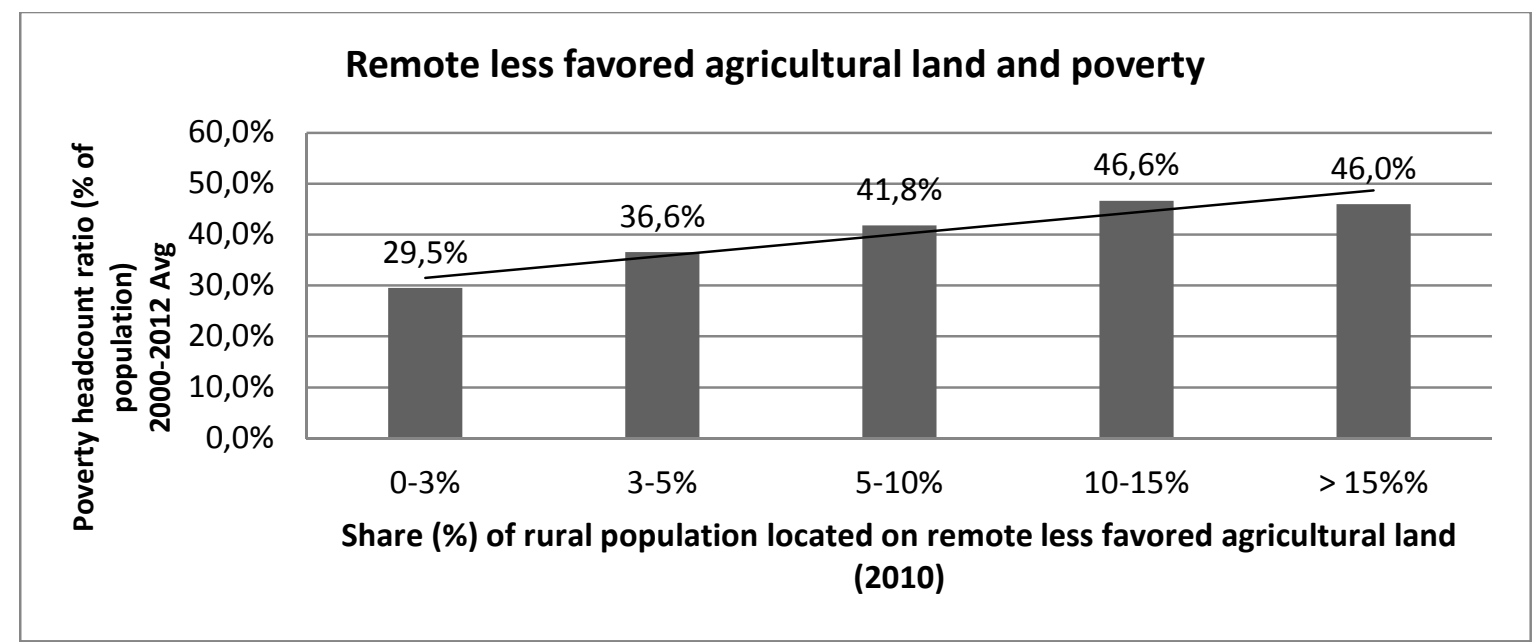

Share (\%) of rural population located on remote less favored agricultural land (average 8.8\%, median 6.9\%), which is less favored agricultural land (LFAL) with limited market access (i.e. located in remote areas). Market access is identified as less than five hours of travel to a market city with a population of 50,000 or more, as defined by Nelson (2008). 98 countries, of which 18 (0-3\% on remote LFAL), 20 (3-5\%), 28 (5-10\%), 20 (10-15\%) and 13 (> 15\%).

Population below $\$ 2$ a day is the percentage of the population living on less than $\$ 2.00$ a day at 2005 international purchase power parity (PPP) prices. For eight countries, the poverty headcount ratio is at national poverty line (\% of population). Across all countries, the average poverty rate was $40.9 \%$, and the median $35.4 \%$.

Low and middle-income (or developing) countries are economies with 2013 per capita income of $\$ 12,745$ or less.

Source: World Bank, World Development Indicators, available from http://databank.worldbank.org/data and Barbier and Hochard (2014a). 
Following the approach developed by Ravallion (2012) the analyze the impacts of initial poverty levels on poverty-reducing growth, Barbier and Hochard (2014b) examine whether the spatial distributions of rural population on less favored agricultural land, less favored agricultural areas and remote LFAL in 2000 affect changes in poverty rates in 83 developing countries from 20002012. They find no evidence that these 2000 spatial distributions of rural population have a direct impact on poverty from 2000-2012. But there is a significant indirect impact through lowering the poverty-reducing impact of income growth over 2000-2012. The latter effects are summarized in Table 4. In all cases, as the share of rural population on either less favored agricultural land and remote agricultural areas increases, so does the poverty rate across the sample of 83 developing countries.

Table 4. The impacts on poverty of the spatial distributions of rural populations

\begin{tabular}{lccc}
\hline & Initial level & Final level & $\begin{array}{c}\text { per cent change in } \\
\text { poverty rate per year }\end{array}$ \\
$\begin{array}{l}\text { Share (\%) of rural population on less favoured } \\
\text { agricultural land (LFAL) }\end{array}$ & $38.15 \%$ & $59.10 \%$ & $0.92 \%$ to $0.99 \%$ \\
$\begin{array}{l}\text { Share (\%) of rural population in less favoured } \\
\text { agricultural areas (LFAA) }\end{array}$ & $40.04 \%$ & $60.83 \%$ & $0.97 \%$ to $1.11 \%$ \\
$\begin{array}{l}\text { Share (\%) of rural population located on remote } \\
\text { LFAL }\end{array}$ & $8.50 \%$ & $16.90 \%$ & $0.35 \%$ to $0.47 \%$ \\
$\begin{array}{l}\text { Share (\%) of rural population on LFAL located on } \\
\text { remote LFAL }\end{array}$ & $24.74 \%$ & $43.55 \%$ & $0.95 \%$ to $1.32 \%$ \\
\hline
\end{tabular}

The initial level is based on the mean and the final level on a one-standard-deviation change in the relevant variables listed in the far-left column for the sample of 83 developing countries.

Source: Barbier and Hochard (2014b).

To summarize, the concentration of rural populations on remote and less favored agricultural land remains an intractable feature of underdevelopment in many low and middle-income economies. The most critical population groups appear to be rural populations on less favoured and degrading agricultural land without market access. Moreover, the numbers of rural people in these remote and marginal agricultural lands appears to be increasing. In addition, across a wide range of developing countries, as more rural people are located on remote and less-favored agricultural land, the result is a substantial reduction in the ability of income growth to reduce overall poverty. These results lend credence to concerns about the prevalence of geographical poverty traps in the rural areas of developing countries (Barbier 2012; Bird et al. 2002 and 2010; Jalan and Ravallion 2002; Kanbur and Venables 2005; Kraay and McKenzie 2014).

\section{Implications for green growth}

Table 5 summarizes the key structural features of developing countries that have been emphasized in this paper. Not only do poorer economies have lower per capita incomes and higher poverty rates, but they also are more resource dependent and have a higher share of their rural population located on remote less favored agricultural land. But the summary table also indicates that resource dependency and the concentration of some rural populations in remote and marginal 
agricultural areas remains widespread across all developing countries, including many at the upper middle-income level.

Table 5. Summary of key structural feature of developing economies

\begin{tabular}{lcccc}
\hline & $\begin{array}{c}\text { GDP per capita } \\
\text { (2005 US\$) }\end{array}$ & $\begin{array}{c}\text { Poverty headcount } \\
\text { ratio (\% of } \\
\text { population) }\end{array}$ & $\begin{array}{c}\text { Primary product } \\
\text { exports (\% of } \\
\text { merchandise } \\
\text { exports) }\end{array}$ & $\begin{array}{c}\text { Share (\%) of rural } \\
\text { population on } \\
\text { remote less } \\
\text { favored }\end{array}$ \\
\hline Low income & $\mathbf{2 0 0 0 - 2 0 1 2 ~ A v g ~}$ & $\mathbf{2 0 0 0 - 2 0 1 2 ~ A v g ~}$ & $\mathbf{2 0 0 0 - 2 0 1 2 ~ A v g ~}$ & $\begin{array}{c}\text { agricultural land } \\
\mathbf{2 0 1 0}\end{array}$ \\
\hline Lower middle-income & $\mathbf{2 , 4 0 9}$ & $64.1 \%$ & $66.6 \%$ & $10.2 \%$ \\
\hline Upper middle-income & 6,101 & $23.4 \%$ & $53.5 \%$ & $7.8 \%$ \\
\hline All developing & $\mathbf{2 , 0 7 7}$ & $15.3 \%$ & $43.7 \%$ & $6.7 \%$ \\
\hline
\end{tabular}

98 countries, of which 45 are low income, 39 are lower middle-income and 14 are upper middle income.

Low-income economies are those in which $2013 \mathrm{GNI}$ per capita was $\$ 1,045$ or less. Lower-middle-income economies are those in which $2013 \mathrm{GNI}$ per capita was between $\$ 1,046$ and $\$ 4,125$. Upper-middle-income economies are those in which 2013 GNI per capita was between $\$ 4,126$ and $\$ 12,745$.

Source: World Bank, World Development Indicators, available from http://databank.worldbank.org/data and Barbier and Hochard (2014a).

The persistence of these features in poorer countries suggests that they cannot be overcome emphasizing solely structural transformation that promotes growth of high-productivity industries and highly commercialized agricultural and service activities. Such structural transformation "green" or otherwise - is unlikely to benefit the rural poor on less favored lands and in remote areas. It is also unlikely to end the "enclavism" predominating in primary production and resourcebased activities. Instead additional policies are required to address the two "stylized facts" associated with resource dependency and rural poverty. First, there is the need for specific policies aimed at improving the efficiency and sustainability of primary production for economy-wide gains, and second, additional targeted policies are needed for the rural poor on less favored agricultural lands and in remote areas.

Various examples of successful and sustainable resource-based development, from the late $19^{\text {th }}$ century to the present, highlight the three key factors in this process (Barbier 2011):

- Resource-enhancing technological change in primary production activities.

- Strong forward and backward linkages between the resource-based primary production sector and the rest of the economy.

- Substantial knowledge spillovers in primary production and across resource-based activities.

First, country-specific knowledge and technical applications in the resource extraction sector can effectively expand what appears to be a "fixed" resource endowment of a country. For example, Wright and Czelusta (2004) document this process for several successful mineral-based economies over the past 30 to 40 years: "From the standpoint of development policy, a crucial aspect of the process is the role of country-specific knowledge. Although the deep scientific bases for progress are undoubtedly global, it is in the nature of geology that location-specific knowledge continues to 
be important....the experience of the 1970s stands in marked contrast to the 1990s, when mineral production steadily expanded primarily as a result of purposeful exploration and ongoing advances in the technologies of search, extraction, refining, and utilization; in other words by a process of learning."

Second, there must be strong linkages between the resource sector and frontier-based activities and the rest of the economy. For example, Findlay and Lundahl (1999, pp.31-2) note the importance of such linkages in promoting successful "staples-based" development during the 1870-1914 era: "not all resource-rich countries succeeded in spreading the growth impulses from their primary sectors....in a number of instances the staples sector turned out to be an enclave with little contact with the rest of the economy....The staples theory of growth stresses the development of linkages between the export sector and an incipient manufacturing sector."

Third, there must be substantial knowledge spillovers arising from the extraction and use of resources and land in the economy. For example, the rise of the American minerals-based economy from 1879 to 1940 can be at least partly attributed to the infrastructure of public scientific knowledge, mining education and the "ethos of exploration" (David and Wright 1997). Creating knowledge spillovers across firms is one of crucial "components of successful modern-regimes of knowledge-based economic growth" in several successful mineral-based economies over the past 30 to 40 years (Wright and Czelusta 2004). There is also evidence of this occurring in successful resource-based industries in some developing economies, such as Malaysia, Thailand and Brazil (Barbier 2011).

Although there have been few examples of a successful resource-based development strategy for many developing economies perhaps as a guide to such a strategy, policymakers should look to the three successful, resource-rich small open economies identified by Gylfason (2001) Botswana, Malaysia and Thailand. Although these countries still face problems in managing their natural resources and overcoming dualism and poverty, several lessons for improving the sustainability of other small resource-dependent developing economies can still be learned from these three country examples. ${ }^{3}$

First, the type of natural resource endowment and primary production activities is not necessarily an obstacle to implementing a successful strategy. Botswana's economy is largely dependent on minerals, Thailand started out as almost exclusively an agricultural-based food exporter and Malaysia built its success first on mineral and timber reserves, then plantation tree crops, and finally, by developing a highly diversified economy. All three countries are testament to the fact that neither the abundance of natural resources nor the type of resources exploited for primary production are inherently a "curse" or a "blessing" on economic development (Barbier 2005 and 2011; Gylfason 2001; Sarraf and Jiwanji 2001; van der Ploeg 2011). It is the institutions and policies

\footnotetext{
${ }^{3}$ For further discussion of the long-run natural resource management and development strategies of Botswana, Malaysia and Thailand, see in particular Barbier (2005 and 2011), Coxhead and Jayasuriya (2003), limi (2007), Lange and Wright (2004), Sarraf and Jiwanji (2001) and Vincent et al (1997).
} 
of an economy that determines whether or not resource-based development will be successful in the long run. Or, as Sarraf and Jiwanji $(2001$, p.3) have argued, "the natural resource curse is not necessarily the fate of resource abundant countries...sound economic policies and good management of windfall gains can lead to sustained economic growth."

Second, because resource endowments, primary production activities and the historical, cultural, economic and geographical circumstances of each country are different, the type of successful development strategy adopted will also vary for different economies. For example, Thailand and Malaysia initially embarked on similar strategies to encourage sustainable primary production and resource use, but the primacy of agriculture in Thailand plus differing economic and social conditions meant that its diversification strategy eventually diverged from that of Malaysia.

Third, the development strategy has to be comprehensive. The success of Malaysia and Thailand in diversifying their economy, and Botswana in sustaining growth, suggests that reliance on primary product exports is not necessarily an obstacle to development. But it must be accompanied by specific policies to improve the competitiveness and export potential of the main primary production activities of the economy, while limiting resource over-exploitation and waste. In addition, the resulting increased returns and revenues generated from primary production activities must be re-invested in the industrial activities, infrastructure, health services, and the education and skills necessary for long-term economic development.

Finally, no strategy is perfect. In all three economies, important sectors and populations have yet to gain significantly from improving the sustainability of the main primary producing sectors. In Malaysia, there is concern about the continuing destruction of forests, especially in the more remote Sabah and Sarawak Provinces, and the expansion of oil palm plantations. In Thailand, the loss of mangroves, growing pollution problems and the failure to instigate development in upland regions are major issues. Botswana has still to grapple with a stagnant agricultural sector, large numbers of people living in fragile environments and widespread rural poverty. Finding ways to broaden the economy-wide benefits and improve the sustainability of resource-dependent economies is an ongoing challenge for such small open economies.

However, encouraging more efficient and sustainable resource-based development in developing economies may not on its own eliminate the persistent problem of widespread rural poverty. Specific policies need to be targeted at the poor where they live, especially the rural poor clustered on less favored agricultural lands and remote areas. Even developing economies that have pursued successful resource-based development, such as Botswana, Malaysia and Thailand, are still grappling with these structural poverty problems.

Thus, there is a need for targeted policies to these households to raise real wages and alleviate poverty concentrated on less favored agricultural lands and remote areas, which involve (Barbier 2012a) : 
- Targeting investments and policies to improve the livelihoods and productivity of traditional agricultural in these locations.

- Appropriate targeting of research, extension and agricultural development to improve the livelihoods of the poor, increase employment opportunities and reduce environmental degradation.

- Better market integration for the rural poor through developing public services and infrastructure in remote and less favored agricultural regions, such as extension services, roads, communications, protection of property, marketing services and other strategies to improved smallholder accessibility to larger markets.

Such a strategy supports recent efforts to target investments directly to improving the livelihoods of the rural poor in remote and fragile environments (World Bank 2008). For example, in Ecuador, Madagascar and Cambodia poverty maps have been developed to target public investments to geographically defined sub-groups of the population according to their relative poverty status, which could substantially improve the performance of the programs in term of poverty alleviation (Elbers et al. 2007). A World Bank study that examined 122 targeted programs in 48 developing countries confirms their effectiveness in reducing poverty, if they are designed properly (Coady et al. 2004). A review of poverty alleviation programs in China, Indonesia, Mexico and Vietnam also finds evidence of "the value in specifically targeting spatially disadvantaged areas and households", although the benefits are larger when programs, such as PROGRESA in Mexico, were successful in employing second-round targeting to identify households in poor locations and thus reducing leakages to non-poor households (Higgins et al. 2010, p. 20).

Appropriate targeting of research, extension and agricultural development has been shown to improve the livelihoods of the poor, increase employment opportunities and even reduce environmental degradation (Barbier 2005 and 2010; Carr 2009; Caviglia-Harris and Harris 2008; Coxhead et al. 2002; Dercon et al. 2009; Maertens et al. 2006). Empirical evidence of technical change, increased public investments and improved extension services in remote regions indicates that any resulting land improvements that do increase the value of homesteads can have a positive effect on both land rents and reducing agricultural expansion (Bellon et al. 2005; Coxhead et al. 2002; Dercon et al. 2009; Dillon et al. 2011; Maertens et al. 2006; Sills and Caviglia-Harris 2008).

Improving market integration for the rural poor may also depend on targeted investments in a range of public services and infrastructure in remote and ecologically fragile regions, such as extension services, roads, communications, protection of property, marketing services and other strategies to improve smallholder accessibility to larger markets (Barrett 2008; World Bank 2008). For example, for poor households in remote areas of a wide range of developing countries, the combination of targeting agricultural research and extension services to poor farmers combined with investments in rural road infrastructure to improve market access appears to generate positive development and poverty alleviation benefits (Ansoms and McKay 2010; Bellon et al. 2005; Cunguara and Damhofer 2011; Dercon et al. 2009; Dillon et al. 2011; Müller and Zeller 2002; 
Pattanayak et al. 2003;Yamano and Kijima 2010). In Mexico, poverty mapping was found to enhance the targeting of maize crop breeding efforts to poor rural communities in less favorable and remote areas (Bellon et al. 2005). In the Central Highlands of Vietnam, the introduction of fertilizer, improved access to rural roads and markets, and expansion of irrigation increased dramatically the agricultural productivity and incomes (Müller and Zeller 2002).

However, any policy strategy targeted at improving the livelihoods of the rural poor located in remote and less favored agricultural regions should be assessed against an alternative strategy, which is to encourage greater out-migration from these areas. As pointed out by Lall et al. (2006, p. 48), rural development is essentially an indirect way of deterring migration to cities, yet because of the costliness of rural investments, "policies in developing countries are increasingly more concerned with influencing the direction of rural to urban migration flows - e.g. to particular areas - with the implicit understanding that migration will occur anyway and thus should be accommodated at as low a cost as possible." Rarely, however, are the two types of policy strategies, investment in poor rural areas and targeted outmigration, directly compared. In addition, only recently have the linkages between rural out-migration, smallholder agriculture and land use change and degradation in remote and marginal areas been analyzed (Mendola 2008 and 2012; Gray 2009; Greiner and Sakdapolrak. 2012; VanWey et al. 2012). Researching such linkages will become increasingly important to understanding the conditions under which policies to encourage greater rural out-migration should be preferred to a targeted strategy to overcome poverty in remote and fragile areas. It may be, as argued by the World Bank (2008, p. 49), that "until migration provides alternative opportunities, the challenge is to improve the stability and resilience of livelihoods in these regions". As this paper has pointed out, this may become a critical feature in the design of structural transformation policies to overcome widespread rural poverty in many developing economies.

\section{Conclusion}

In answer to the question posed by the title of this paper, green growth is relevant for poor economies, only if it includes policies that are consistent with their key structural features of natural resource use and poverty. First, many economies are resource-dependent, in that a large share of their exports consists of primary products, and thus they remain highly reliant on a commercial primary products sector. Second, many developing countries have a substantial share of their rural population located on less favored (marginal) agricultural land and in remote areas.

Thus, if green growth is to be a catalyst for economy-wide transformation and poverty alleviation in developing countries, then it must be accompanied by policies aimed directly at overcoming these two structural features. Policies and reforms must be instigated that foster forward and backward linkages of primary production, enhance its integration with the rest of the economy, and improve opportunities for innovation and knowledge spillovers. Rural poverty, especially the persistent concentration of the rural poor on less favored agricultural lands and in remote areas, needs to be addressed by additional targeted policies and investments. Finally, policies to 
promote rural-urban migration should take into account the linkages rural out-migration, smallholder agriculture and land use change, and degradation in remote and marginal areas.

\section{References}

- Ansoms, A. and A. McKay. 2010. "A quantitative analysis of poverty and livelihood profiles: The case of rural Rwanda." Food Policy 35:584-598.

- Asian Development Bank (ADB) and Asian Development Bank Institute (ADBI). 2013. Low-Carbon Green Growth in Asia: Policies and Practices. ADB and ADBI, Manila, The Philippines.

- Barbier, E.B. 2005. Natural Resources and Economic Development. Cambridge University Press, Cambridge, UK.

- Barbier, E.B. 2010. "Poverty, development and environment." Environment and Development Economics 15:635-660.

- Barbier, E.B. 2011. Scarcity and Frontiers: How Economies Have Developed Through Natural Resource Exploitation. Cambridge University Press, Cambridge.

- Barbier, E.B. 2012a. "Natural Capital, Ecological Scarcity and Rural Poverty." Policy Research Working Paper No. 6232. The World Bank, Washington, DC, October.

- Barbier, E.B. 2012b. "The Green Economy Post Rio+20." Science 338:887-888.

- Barbier, E.B. 2014. "Climate change mitigation policies and poverty." WIREs Climate Change 5:483-491 doi: 10.1002/wcc.281.

- Barbier, E.B. and J.P. Hochard, 2014a. "Land Degradation, Less Favored Lands and the Rural Poor: A Spatial and Economic Analysis." A Report for the Economics of Land Degradation Initiative. Department of Economics and Finance, University of Wyoming. Available from: www.eldinitiative.org

- Barbier, E.B. and J.P. Hochard, 2014. "Poverty and the Spatial Distribution of Rural Population." Policy Research Working Paper No. 7101. The World Bank, Washington, DC, November.

- Bellon, M.R., D. Hodson, D. Bergvinson, D. Beck, E. Martinez-Romero and Y. Montoya. 2005. "Targeting agricultural research to benefit poor farmers: Relating poverty mapping to maize environments in Mexico." Food Policy 30:476-492.

- Bird, K., D. Hulme, K. Moore and A. Shepherd. 2002. "Chronic Poverty and Remote Rural Areas." CPRC Working Paper No. 12. Chronic Poverty Research Centre, University of Manchester, Manchester.

- Bird, K., A. McKay and I. Shinyekwa. 2010. "Isolation and poverty: The relationship between spatially differentiated access to goods and services and poverty." ODI Working Paper 322, Overseas Development Institute, London.

- Boucher, D., P. Elias, K. Lininger, C. May-Tobin, S. Roquemore and E. Saxon. 2011. The Root of the Problem: What's Driving Tropical Deforestation Today? Union of Concerned Scientists, Cambridge, MA.

- Bowen, A. and Frankhauser, S. 2012. "The green growth narrative: Paradigm shift or just spin?" Global Environmental Change 21:1157-11159

- Bridge, G. 2008 "Global production networks and the extractive sector: governing resourcebased development" Journal of Economic Geography 8 389-419 
- CGIAR (TAC Secretariat), 1999. CGIAR study on marginal lands: report on the study on CGIAR research priority for marginal lands. Marginal Lands Study Paper No. 1. Food and Agricultural Organization of the United Nations, Rome.

- Carr, D. 2009 "Population and deforestation: why rural migration matters" Progress in Human Geography 33:355-378.

- Caviglia-Harris, J.L. and Harris, D. 2008. "Integrating survey and remote sensing data to analyze land use scale: insights from agricultural households in the Brazilian Amazon." International Regional Science Review 31 115-137.

- Chomitz K, Buys P, De Luca G, Thomas T and Wertz-Kanounnikoff S 2007 At Loggerheads? Agricultural Expansion, Poverty Reduction, and Environment in the Tropical Forests. The World Bank, Washington DC.

- Coady, D., M. Grosh and J. Hoddinott. 2004. "Targeting outcomes redux." World Bank Research Observer 19(1):61-85.

- Comprehensive Assessment of Water Management in Agriculture (CAWMA). 2008. Water for Food, Water for Life: A Comprehensive Assessment of Water Management in Agriculture. London: Earthscan and International Water Management Institute, Colombo, Sri Lanka

- Coxhead, I. and S. Jayasuriya. 2003. The Open Economy and the Environment: Development, Trade and Resources in Asia. Edward Elgar, Northampton, MA.

- Coxhead, I., G.E. Shively and X. Shuai. 2002. "Development policies, resource constraints, and agricultural expansion on the Philippine land frontier" Environment and Development Economics 7:341-364.

- Cunguara, B. and I. Darnhofer. 2011. "Assessing the impact of improved agricultural technologies on household income in rural Mozambique." Food Policy 36:378-390.

- DeFries R., T. Rudel, M. Uriarte and M. Hansen 2010. "Deforestation driven by urban population growth and agricultural trade in the twenty-first century." Nature Geoscience 3:178-801.

- Deininger, K., D. Byerlee, J. Lindsay, A. Norton, H. Selod and M. Stickler. 2011. Rising Global Interest in Farmland: Can it Yield Sustainable and Equitable Benefits? The World Bank, Washington DC.

- Deininger, K. and D. Byerlee. 2012. "The Rise of Large Farms in Land Abundant Countries: Do They Have a Future?" World Development 40:701-714.

- Dercon, S. 2012. "Is Green Growth Good for the Poor?" Policy Research Working Paper No. 6231. The World Bank, Washington, D.C.

- Dercon, S., D.O. Gilligan, J. Hoddinott and T. Woldehanna. 2009. "The impact of agricultural extension and roads on poverty and consumption growth in fifteen Ethiopian villages." American Journal of Agricultural Economics 91:1007-1021.

- Dillon, A., M. Sharma and X. Zhang. 2011. "Estimating the impact of rural investments in Nepal." Food Policy 36:250-258.

- Elbers, C., T. Fujii, P. Lanjouw, B. Özler and W. Yin. 2007. "Poverty alleviation through geographic targeting: How much does disaggregation help?" Journal of Development Economics 83:198-213.

- Fankhauser, S., A. Bowen, R. Calel, A. Dechezleprêtre, D. Grover, J. Rydge and M. Sato. 2013. "Who will win the green race? In search of environmental competitiveness and innovation." Global Environmental Change 23:902-913. 
- Findlay, R. and M. Lundahl. 1999. "Resource-Led Growth - a Long-Term Perspective: The Relevance of the 1970-194 Experience for Today's Developing Economies." UNU/WIDER Working Papers No. 162. WIDER, Helsinki

- Food and Agricultural Organization (FAO) of the United Nations, 2006. Global Forest Resources Assessment 2005, Main Report. Progress Towards Sustainable Forest Management. FAO Forestry Paper 147. FAO, Rome.

- Gray, C.L. 2009. "Rural out-migration and smallholder agriculture in the southern Ecuadorian Andes." Population and Environment 30:193-217.

- Greiner, C. and P. Sakdapolrak. 2012. "Rural-urban migration, agrarian change, and the environment in Kenya: a critical review of the literature." Population and Environment. Published online DOI 10.1007/s11111-012-0178-0.

- Gylfason, T. 2001 "Nature, power, and growth." Scottish Journal of Political Economy 48:558-588.

- Haines, A, McMichael AJ, Smith KR, Roberts J, Woodcock J, Markandya A, Armstrong BG, Campbell-Lendrum D, Dangour AD, Davies $M$, et al. 2009. Public health benefits of strategies to reduce greenhouse-gas emissions: overview and implications for policy makers. Lancet 374:2104-2114. DOI:10.1016/S0140-6736(09)61759-1

- Hallegatte, S., G. Heal, M. Fay and D. Treguer. 2011. "From Growth to Green Growth", Policy Research Working Paper WPS 5872, The World Bank, Washington, D.C., November.

- Higgins, K., K. Bird and D. Harris. 2010. "Policy responses to the spatial dimensions of poverty." ODI Working Paper 328. Overseas Development Institute, London.

- limi, Atsushi. 2007. "Escaping from the Resource Curse: Evidence from Botswana and the Rest of the World." IMF Staff Papers 54:663-699.

- Jalan, J. and M. Ravallion. 2002. "Geographic Poverty Traps? A Micro Model of Consumption Growth in Rural China." Journal of Applied Econometrics 17:329-346.

- Kanbur, R. and A.J. Venables, eds. 2005. Spatial Inequality and Development. Oxford University Press, Oxford.

- Kraay, A. and D. McKenzie. 2014. "Do poverty traps exist? Assessing the evidence." Journal of Economic Perspectives 28:127-148.

- Krueger, A. 2011. "Comments on 'New Structural Economics' by Justin Yifu Lin." World Bank Research Observer 26:222-226.

- Lall, S.V., H. Selod and Z. Shalizi. 2006. "Rural-Urban Migration in Developing Countries: A Survey of Theoretical Predictions and Empirical Findings." World Bank Policy Research Working Paper 3915. The World Bank, Washington DC, May.

- Lambin, E.F. and P. Meyfroidt. 2011. "Global land use change, economic globalization, and the looming land scarcity." Proceedings of the National Academy of Sciences 108:3465-3472.

- Lange, G.-M. and M. Wright 2004. "Sustainable development and mineral economies: the example of Botswana." Environment and Development Economics 9(4):485-505.

- Lin, J.Y. 2011. "New Structural Economics: A Framework for Rethinking Development." World Bank Research Observer 26:193-221.

- Maertens, M. M. Zeller and R. Birner. 2006 "Sustainable agricultural intensification in forest frontier areas." Agricultural Economics 34:197-206.

- McMillan, M. and D. Rodrik. 2011. "Globalization, Structural Change, and Productivity Growth." NBER Working Paper No. 17143. National Bureau of Economic Research, Boston, MA. 
- Mendola, M. 2008. "Migration and technological change in rural households: Complements or substitutes?" Journal of Development Economics 85:150-175.

- Mendola, M. 2012. "Review Article: Rural Out-Migration and Economic Development at Origin: A Review of the Evidence." Journal of International Development 24:102-122Müller, D. and Zeller, Z. 2002. "Land use dynamics in the central highlands of Vietnam: a spatial model combining village survey data with satellite imagery interpretation." Agricultural Economics 27:333-354.

- Nelson, A. 2008. "Travel time to major cities: A global map of Accessibility." Global Environment Monitoring Unit - Joint Research Centre of the European Commission, Ispra Italy. Available at http://gem.jrc.ec.europa.eu/.

- Ocampo, J.A., C. Rada and L. Taylor. 2009. Growth and Policy in Developing Countries: A Structuralist Approach. Columbia University Press, New York.

- Organization for Economic Cooperation and Development (OECD). 2011. Towards Green Growth. OECD, Paris.

- Organization for Economic Cooperation and Development (OECD). 2013. Putting Green Growth at the Heart of Development. OECD, Paris.

- Pattanayak, S.K., D.E. Mercer, E. Sills and J-C. Yang. 2003. "Taking stock of agroforestry adoption studies." Agroforestry Systems 57:173-186.

- Pender, J. and P. Hazell. 2000. "Promoting Sustainable Development in Less-Favored Areas: Overview". Brief 1 in J. Pender and P. Hazell (eds.), Promoting Sustainable Development in LessFavored Areas. 2020 Vision Initiative, Policy Brief Series, Focus 4. Washington, DC: International Food Policy Research Institute.

- Ravallion, M. 2012. "Why Don't We See Poverty Convergence?" American Economic Review 102:504-523.

- Resnick, D., F. Tarp and J. Thurlow. 2012. "The Political Economy of Green Growth: Cases from Southern Africa." Public Administration and Development 32:215-228.

- Rodrik, D. 2010. "Making Room for China in the World Economy." American Economic Review: Papers and Proceedings 100:89-93.

- Rudel T 2007 "Changing agents of deforestation: From state-initiated to enterprise driven process, 1970-2000." Land Use Policy 24 35-41

- Sarraf, M. and M. Jiwanji. 2001. "Beating the Resource Curse: The Case of Botswana." Environmental Economics Series. The World Bank Environment Department. The World Bank, Washington DC. World Bank

- Schmalensee, R. 2012. "From 'green growth' to sound policies: An overview." Energy Economics 34:52-56.

- Scott, A., W. McFarland and P. Seth. 2013. Research and Evidence on Green Growth. Overseas Development Institute and the UK Department for International Development, London. http://r4d.dfid.gov.uk/pdf/outputs/EoD/EoD HD064 July2013 GreenGrowth Final.pdf

- Sills, E. and J.L. Caviglia-Harris. 2008. "Evolution of the Amazonian frontier: Land values in Rondônia, Brazil." Land Use Policy 26:55-67.

- Strand, J. and M. Toman. 2010. "'Green Stimulus', Economy Recovery, and Long-Term Sustainable Development." Policy Research Working Paper No. 5163. The World Bank, Washington DC. 
- U.N. Commission on Sustainable Development (UNCSD). 2012. The Future We Want: Zero draft of the outcome document (UNCSD, January 10, 2012, http://www.uncsd2012.org/futurewewant.html).

- United Nations Environmental Programme (UNEP). 2011. Towards a Green Economy: Pathways to Sustainable Development and Poverty Eradication - A Synthesis for Policymakers. UNEP, Nairobi.

- van der Ploeg, R. 2011. "Natural Resources: Curse or Blessing?" Journal of Economic Literature 49:366-420.

- VanWey, L.K., G.R. Guedes and A.O. D'Antona. 2012. "Out-migration and land-use change in agricultural frontiers: insights from Altamira settlement project." Population and Environment 34:44-68.

- Vincent, J.R., R.M. Ali and Associates. 1997. Environment and Development in a Resource-Rich Economy: Malaysia under the New Economic Policy. Harvard Institute for International Development, Harvard University Press.

- World Bank. 2003. World Development Report 2003. World Bank, Washington DC.

- World Bank. 2008. Word Development Report 2008: Agricultural Development. The World Bank, Washington DC.

- World Bank. 2012. Inclusive Green Growth: The Pathways to Sustainable Development. The World Bank, Washington, D.C.

- Wright, G. and J. Czelusta. 2004. "Why Economies Slow: The Myth of the Resource Curse." Challenge 47(2):6-38.

- Yamano, T. and Y. Kijima. 2010. "The association of soil fertility and market access with household income: Evidence from rural Uganda." Food Policy 35:51-59. 

"Sur quoi la fondera-t-il l'économie du monde qu'il veut gouverner? Sera-ce sur le caprice de chaque particulier? Quelle confusion! Sera-ce sur la justice? Il l'ignore."

Pascal

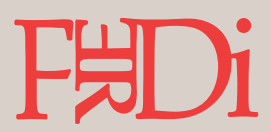

Created in 2003, the Fondation pour les études et recherches sur le développement international aims to promote a fuller understanding of international economic development and the factors that influence it.

\section{$\hookrightarrow$ Contact}

www.ferdi.fr

contact@ferdi.fr

+33 (o)4 73177530 